Paulo Eduardo Benites de Moraes *

Universidade Federal de Rondônia - UNIR

Rosana Cristina Zanelatto Santos **

Universidade Federal de Mato Grosso do Sul - UFMS

\title{
A alegoria como poética do (ex)combro em Manoel de Barros: uma visada benjaminiana
}

Resumo: Walter Benjamin foi dos pensadores que mais adequadamente discutiu a dialética da história como um movimento de extremos, isto é, como experiência presente empobrecida diante das glórias do passado, o que dissimula, ironicamente, uma outra formulação, exposta na IX tese "Sobre o conceito de história": nela ele apresenta a interpretação da alegoria (ex)posta no Angelus Novus, de Paul Klee, como a "facies hippocratica da história" (Benjamin 1984), pensando essa imagem como "o cerne da visão alegórica" (ibidem). A seu tempo, Manoel de Barros dialoga tanto com Klee quanto com Benjamin, num movimento de (ex)posição de cenas episódicas/fragmentos de uma natureza sempre em estado de violência, sofrimento, tédio e morte, apesar de uma aparência de exuberância e de abundância. Neste ensaio, propomo-nos discutir/ler na poesia de Barros essas construções poético-alegóricas da natureza, à luz especialmente da Origem do drama barroco alemão e da tese IX de "Sobre o conceito de história" de Walter Benjamin (1984 e 1986, respectivamente), além de textos de Jeanne Marie Gagnebin (2013) e de Michel Löwy (2005) sobre a alegoria na visada benjaminiana.

Palavras-chave: Alegoria, Poesia, Fragmento, Manoel de Barros, Walter Benjamin

Abstract: Walter Benjamin was one of the philosophers who most appropriately discussed the dialectics of history as a movement of extremes, that is, as an impoverished present experience before the glories of the past, which conceals, ironically, another formulation, exposed in the 9th thesis "On the concept of history": which presents the interpretation of the allegory (ex)put in The Angelus Novus, by Paul Klee, as the "hippocratic facies of history" (Benjamin 1984), thinking this image as "the core of allegorical vision" (ibidem). Manoel de Barros, in his time, dialogues with both Klee and Benjamin, in a movement of (ex)position of episodic scenes/fragments of a nature always in a state of violence, suffering, tedium and death, despite an appearance of exuberance and abundance. In this essay, we propose to discuss/read in Barros' poetry these poetic-allegorical constructions of nature, especially in the light of The Origin of German Tragic Drama and the thesis IX of Theses on the Philosophy of History by Walter Benjamin (1984 and 1986, respectively), as well as texts by Jeanne Marie Gagnebin (2013) and Michel Löwy (2005) on allegory in the Benjamin's perspective.

Keywords: Allegory, Poetry, Fragments, Manoel de Barros, Walter Benjamin 


\begin{abstract}
Como um pescador de pérolas que desce ao fundo do mar, não para escavá-lo e trazê-lo à luz, mas para extrair o rico e o estranho, as pérolas e o coral das profundezas, e trazê-los à superfície, esse pensar sonda as profundezas do passado - mas não para ressuscitá-lo tal como era e contribuir para a renovação de eras extintas (Arendt 1987: 176).
\end{abstract}

\title{
A luz espectral do fragmento
}

Este ensaio traz, de um modo geral e específico, o caráter episódico de alguns acontecimentos que sobrevivem e chegam até nós pelas alegorias, sejam elas poéticas, sejam históricas. Para tanto, faz-se necessário pensar o caráter espectral dessas imagens, encarando-as como manifestações de um desejo, de uma paixão que nunca deixa de existir por completo, de modo que o fragmento, como aquela ferida ${ }^{1}$ cuja cicatriz nos lembra o sofrimento passado, é uma marca que carrega em si a mundanidade e a precariedade de uma época e também da memória humana. Ou podemos pensar - numa clave filosófica - na proposição das temporalidades não lineares, que são as do ser humano, a promoverem cortes transversais onde cabem, a um só tempo, no espaço das ruínas, o esquecimento e a lembrança. Em Walter Benjamin, vislumbramos isso especialmente em dois textos: a Origem do drama barroco alemão, publicada em 1928, depois de ter sido recusada como tese de livre-docência na Universidade de Frankfurt, e a tese IX de "Sobre o conceito de história", datada de 1940, ano da morte do autor.

Sobre a importância da visada benjaminiana acerca da alegoria, escreve Jeanne Marie Gagnebin (2013: 35): “[...] a reabilitação da alegoria por Benjamin será uma reabilitação da história, da temporalidade e da morte na descrição da linguagem humana”.

A fim de singularizar nossas ideias acerca da alegoria como (ex)posta por Benjamin, discutiremos neste texto como as ruínas são construídas, ao modo do fragmento/da ferida, em alguns poemas de Manoel de Barros. A articulação entre o pensamento de Benjamin e a poética de Barros é indispensável para pensarmos a capacidade criativo-reflexiva tanto da filosofia quanto da poesia; ambas são espaços de debate e de crítica de si mesmas e dos saberes do mundo. Barros (re)apropria-se do fragmento/ferida como postulado por Benjamin, promovendo um ponto de inflexão poética num diálogo alegórico tanto com o anjo da história benjaminiano quanto com o Angulus Novus de Paul Klee, (re)abrindo a cicatriz das narrativas humanas para um devir poético do tempo, que se num primeiro momento parece uma poética do inacabado é de fato uma poética do tédio.

\section{Fragmento/ferida e alegoria em Benjamin e Barros}

Manoel de Barros foi um poeta consciente da importância do tédio da vida e de sua relação com o tempo para a poesia. Em uma de suas mais célebres entrevistas, ${ }^{2}$ quando perguntado sobre a duração da vida, ele propôs uma solução material-poética: 
O tempo só anda de ida.

A gente nasce, cresce, envelhece e morre.

Para não morrer

É só amarrar o tempo no poste.

Eis a ciência da poesia:

Amarrar o tempo no poste!

E respondo mais: dia que a gente estiver com tédio

de viver é só desamarrar o tempo do poste. (Barros 2008: 30)

Se à primeira vista "amarrar o tempo no poste" marca a suspensão do tempo cronológico que açoda o ser humano, "desamarrar o tempo do poste" é uma solução para o problema do tédio da vida que nos arrasta vagarosamente em meio a experiências esvaziadas de sentido. Ao recordarmos a grande aporia do tempo, especificamente a partir de Santo Agostinho (1980: 265) no "Livro XI" das Confissões quando ele se indaga retoricamente: "Que é, por conseguinte, o tempo? Se ninguém me perguntar, eu o sei; se eu quiser explicá-lo a quem me fizer essa pergunta, já não saberei dizê-lo”, teremos a relação paradoxal do sujeito com o tempo. E, na esteira da nossa proposição, com o tédio da vida.

Em seu poema-entrevista, Manoel de Barros não ajuda a resolver o paradoxo, porém deixa entrever as palavras como refúgio para ideias que não devem ser reveladas, seja por serem secretas, seja por serem geradoras de sofrimento. A ideia do tédio gera angústia. “Embora a palavra 'tempo' tenha o pendor para significar uma única realidade singular, não é menos um termo polissêmico com que se harmoniza a conceituação de um tempo plural, [...]" (Nunes 2013: 70). A relação poética estabelecida entre o tempo e o poste reorganiza o modo como o sujeito se coloca diante do tédio da vida, passando a corresponder "[...] a uma variação possível do mundo real" (ibidem). A imagem de "amarrar o tempo no poste" ganha então status de alegoria diante do tédio da vida à espera da morte, porque "O tempo [cronológico] só anda de ida", não havendo a possibilidade do retorno, nem da permanência.

No capítulo "Alegoria e drama barroco" da Origem do drama barroco alemão, Benjamin (1984: 184) atribui a desvalorização da alegoria como princípio ilustrativo ao preconceito classicista, procurando demonstrar que ela "[...] não é frívola técnica de ilustração por imagens, mas expressão, como a linguagem, e como a escrita. Nisso, exatamente, reside o experimentum crucis". Essa percepção revisita o conceito retórico da alegoria como tópos de pensamento, porém inserindo-a em uma relação dialética e não necessariamente de semelhança substitutiva.

Os versos de Barros, além de apontarem a alegoria como uma experiência dialética de extremos (Benjamin 1984: 182) - o tempo, com a possibilidade poético-linguística da reconfiguração, e o poste, como estrutura material fixada em algum ponto dos lugares -, 
também dizem poeticamente o que Benjamin já apontara quanto ao barroco:

[...] a alegoria mostra ao observador a facies hippocratica da história como protopaisagem petrificada. A história em tudo o que nela desde o início é prematuro, sofrido e malogrado, se exprime num rosto - não, numa caveira. E porque não existe, nela, nenhuma liberdade simbólica de expressão, nenhuma harmonia clássica da forma, em suma, nada de humano, essa figura, de todas a mais sujeita à natureza, exprime, não somente a existência humana em geral, mas, de modo altamente expressivo, e sob a forma de um enigma, a história biográfica de um indivíduo. (1984: 188)

"Amarrar o tempo no poste" traduz adequadamente a cristalização/petrificação de uma protopaisagem construída pela inserção racional da narrativa humana no tempo histórico, lembrando-nos de que a vida é declínio, porque quando nascemos começamos a nos entediar e a morrer. O poste, como artefato humano constituído de materiais resistentes como a madeira, o concreto, e pelo qual - se pensarmos nos postes de transmissão elétrica - passa a modernidade, leva-nos a (des)crer da aparência da solidez das coisas criadas para dar um conforto - (também aparente) ao homem na espera da morte. O tempo, como categoria ontológica, tem o seu aspecto cronológico barrado pela potência do poste poético de Manoel de Barros ao qual se encontra alegoricamente atado. 0 poste manoelino serve, ainda, como obstáculo provisório para barrar a "visão devastadora do tempo e da história", "em oposição ao ideal de eternidade que o símbolo [cristalizado] encarna” (Gagnebin 2013: 31). O poste é a presença mundana que, subjetivada e imaginativa, aproxima o sujeito de uma experiência - a do tempo - que está fora de si mesmo e que não pode ser controlada. Em tempo: as observações de Gagnebin referem-se ao confronto entre símbolo e alegoria na Origem do drama barroco alemão.

A aproximação que ora fazemos entre a alegoria barroca, como tratada por Benjamin, e a poesia de um escritor romântico-moderno como Barros (naquilo que esse adjetivo tem de paradoxal $)^{3}$ nos foi sugerida pelo próprio Benjamin e referendada por Gagnebin (2013: 37):

É o choque entre o desejo de eternidade e a consciência aguda da precariedade do mundo que, segundo Benjamin, está na fonte da inspiração alegórica [...] Por isso ela floresce na idade barroca, dilacerada entre os dogmas da fé cristã e a cruel imanência do político, por também voltará num Baudelaire, dividido entre a visão de uma "vida anterior" harmoniosa e a de uma modernidade autodevoradora.

Para Benjamin, a alegoria barroca é construída na linguagem, na referência à concretude das coisas no mundo. O poste manoelino é um exemplo dessa construção. 
[...] o caráter precioso dessa forma de expressão, como no Barroco em geral, reside, ao contrário, em grande parte na regressão extrema ao nível do vocabulário concreto. A mania de empregar essas palavras [preciosas], e de recorrer a antíteses elegantes, é tão marcada, que as abstrações, quando parecem inevitáveis, são acompanhadas de elementos concretos, formando novas palavras. (1984: 221)

Não são somente novas palavras que se formam; são novas significações, pois o que dura não são as palavras; o que dura é a beleza de "um objeto de saber”, pois “[...] o que é certo é que nada existe de belo que não tenha em seu interior algo que mereça ser sabido" (Benjamin 1984: 203). Somos seres de palavras ou pelo menos a metade de nós o é.

Sou pela metade sempre, ou menos da metade. A outra metade tenho que desforrar nas palavras. Ficar montando, em versos, pedacinhos de mim, ressentidos, caídos por aí, para que tudo afinal não se disperse. Um esforço para ficar inteiro é que é essa atividade poética. (Barros 1990: 308)

Ontologicamente, o eu lírico manoelino reconhece a necessidade de manter-se íntegro, o que requer, também, a presença do passado. Os pedacinhos, "ressentidos, caídos por aí", são os fragmentos de passado que se acumulam incessantemente, à espera de uma solução de continuidade. Porém, como juntar esses pedacinhos de si? Não basta somente a linguagem; é preciso recorrer à linguagem poética, a um só tempo, lugar da ausência e do visgo. Ao longo do projeto poético de Barros, há uma visível dedicação ao passado, posta em diversas temáticas: a infância, as lembranças, o espaço original do homem pantaneiro.

Talvez a figura que melhor represente os momentos dedicados ao passado, em Barros, seja a do escavador de memórias. O sujeito poético apresenta-se tal qual um arqueólogo do instante, que emerge pela des-figuração da linguagem, isto é, há menos uma intenção de linguagem como meio de transmissão da comunicação do que como um expediente no qual seus sonhos, seus devaneios e suas memórias se revelam. A trilogia Memórias inventadas é um bom exemplo de reunião desses poemas arqueológicos. Divididas em três infâncias (a primeira, a segunda e a terceira), fiquemos com o poema de abertura de $A$ Primeira infância:

\section{Escova}

Eu tinha vontade de fazer como os dois homens que vi sentados na terra escovando osso. No começo achei que aqueles homens não batiam bem. Porque ficavam sentados na terra o dia inteiro escovando osso. Depois aprendi que aqueles homens eram arqueólogos. E que eles faziam o serviço de escovar ossos por amor. E que eles queriam encontrar nos ossos vestígios de antigas civilizações que estariam enterradas por séculos naquele chão. Logo pensei de escovar palavras. Porque eu havia lido em algum lugar que as palavras eram conchas de 
clamores antigos. Eu queria ir atrás dos clamores antigos que estariam guardados dentro das palavras. Eu já sabia também que as palavras possuem no corpo muitas oralidades remontadas e muitas significâncias remontadas. Eu queria escovar as palavras para escutar o primeiro esgar de cada uma. Para escutar os primeiros sons, mesmo que ainda bígrafos. Comecei a fazer isso sentado em minha escrivaninha. Passava horas inteiras, dias inteiros fechado no quarto, trancado, a escovar palavras. Logo a turma perguntou: o que eu fazia o dia inteiro trancado naquele quarto? Eu respondia a eles, meio entressonhado, que eu estava escovando palavras. Eles acharam que eu não batia bem. Então eu joguei a escova fora. (Barros 2008: 15)

Parece-nos sintomático que o poema "Escova" esteja colocado na abertura da "primeira infância". A escova, utensílio de trabalho dos arqueólogos para escavar os vestígios de antigas civilizações, pode ser tomada, metonimicamente, como indício de um processo mais complexo. Escavação, no sentido arqueológico do termo (ảpxń), pode significar tanto origem quanto poder. Exploremos o primeiro significado em relação à poética de Manoel de Barros.

A "primeira infância", onde se encontra o poema "escova", é o espaço originário, primevo, tempo passado só alcançado com o uso da "escova". Isso aparece em outros momentos ao longo da obra de Barros, o que nos leva a pensar sobre as razões pelas quais o ato poético se dá por meio de um retorno ao princípio. Em entrevista, quando solicitado para fazer uma análise comparativa de seus contemporâneos, como João Cabral de Melo Neto, Jorge de Lima, Murilo Mendes e Carlos Drummond de Andrade, ele respondeu:

Poesia está sempre no escuro regaço das fontes. Sofro medo de análise. Ela enfraquece a escureza das fontes; seus arcanos. Desses grandes poetas, que admiro e leio com devoção, eu não faria análise nunca. Nem comparativa. Primeiro porque não sei decompor. Segundo: não tem segundo. A grande poesia há de passar virgem por todos os seus estupradores. Pode ser amada, nunca analisada. Hoje eu fiz uma palavra amanhecer entre aves. A frase não diz nada. Mas tem um toque insujeito a comparações. (Barros 1990: 318)

O "escuro", em Barros, é um elemento inerente à poesia e que denota a origem, a fonte. A ideia de origem, retirada dos sentidos da entrevista, associa-se ao termo "escuro", opondo-se imediatamente ao sentido de claro. Nos sentidos possíveis da entrevista, por meio de um exercício metalinguístico para se pensar o próprio ato poético, a "escureza" do poético restitui as fontes sem a tentativa de torná-las claras, o que seria tarefa da análise e da crítica, pois a poesia é um percurso que se dá por meio da obscuridade na busca da manutenção de sua forma, de sua amorosidade. No mais, o escuro, em Barros, parece ser o locus no qual se sustentam o pensamento e a razão estética do poeta. Isso é visível em versos nos quais a imagem da obscuridade aparece.

Em Poesias, de 1956, num poema no qual o tom narrativo floresce com mais intensidade, vê-se o "encontro de Pedro com o nojo": "Pedro mergulhado em trevas, no quarto, 
pensa no rouxinol e na bomba atômica./As coisas mais importantes lhe aconteciam no escuro [...]" (Barros 1990: 117. Grifos no original). O verso em destaque é uma referência ao escuro, lugar onde as coisas mais importantes acontecem. Noutras vezes, o escuro está vinculado ao eu poético: "Aprendi que no escuro eu enxergo melhor" (Barros 2010: 283). Todo esse ensinamento do escuro, da obscuridade, é uma marca do espaço do pensamento do poeta que reside e é acessado no retorno às origens.

No poema "Miró", de Ensaios fotográficos, ${ }^{4}$ Barros anuncia que é preciso "atingir a expressão fontana" (Barros 2003: 29). A "expressão fontana”, criada a partir da construção imagética de um personagem pintor/poeta, como Miró, revela que o pendor poético deve primar pela "pureza de não saber mais nada"/ "de esquecer os traços e as doutrinas/que aprendera nos livro"/ "desejava atingir a pureza de não saber mais nada" (Barros 2003: 29). Para se atingir a "pureza de não saber mais nada”, é preciso acionar o esquecimento. E para acioná-lo, há um ritual, ensinado pelo eu lírico ainda em "Miró":

Fazia um ritual para atingir essa pureza: ia ao fundo do quintal à busca de uma árvore.

E ali, ao pé da árvore, enterrava de vez tudo aquilo que havia aprendido nos livros.

Depois depositava sobre o enterro uma nobre mijada florestal.

Sobre o enterro nasciam borboletas, restos de insetos, cascas de cigarra, etc.

A partir dos restos de Miró iniciava a sua engenharia de cores.

Muitas vezes chegava a iluminuras a partir de um dejeto de mosca deixado na tela.

Sua expressão fontana se iniciava naquela mancha escura.

O escuro o iluminava.

(Barros 2003: 29)

Novamente a imagem perene do escuro aparece como marca de iluminação, uma antítese semântica que ilustra o fazer artístico de Miró, personagem poético, pintor/poeta, que busca sua fonte de criação no "desaprender". Escurecer e iluminar, como par antitético, são postos com o mesmo sentido dentro do poema de Barros, tanto que escurecer ilumina, ilumina Miró e ilumina o próprio eu lírico.

De pronto, surge uma questão na qual o retorno às origens, à "expressão fontana", implica no acionamento de um estado de espírito que se abre para o diálogo com a tradição. A palavra "fontana" parece seguir o limiar da reconstrução de uma mitologia. Segundo Paz (2012: 75), “[...] o mito é um passado que é um futuro disposto a se realizar num presente”, 
isto é, a recriação (da) e a busca pela origem implicam, necessariamente, na recriação do tempo. Em Manoel de Barros, a palavra fontana tem o papel de recriação do tempo e sugere o retorno ao mito de origem, por meio da voz lírica. Tal retorno pode ser associado à obra de Walter Benjamin, para adentrarmos em um mais um tópico no qual Barros e Benjamin se encontram.

Em seu livro das Passagens, Benjamin constrói o jogo da escavação, refletindo sobre o processo de retorno às origens. Essa reflexão pode ser lida como um movimento do pensamento que desconstrói a noção do tempo cronológico, histórico, fundado nos “[...] três elementos de racionalização do tempo: passado, presente e futuro" (Bornheim 1992: 103). Como demonstrado por Helano Ribeiro (2020: 4), a descontinuidade do tempo em Benjamin no retorno à origem se dá no movimento dialético entre a matriz primeval (Ur) e o salto (Sprung), como se lê no texto do próprio Benjamin (2006: 504):

Origem [Ursprung] - eis o conceito de fenômeno originário transposto do contexto pagão da natureza para os contextos judaicos da história. Agora, nas Passagens, empreendo também um estudo da origem. Na verdade, persigo a origem das formas e das transformações das passagens parisienses desde seu surgimento até seu ocaso, e a apreendo nos fatos econômicos. Estes fatos, do ponto de vista da casualidade, ou seja, como causas não seriam fenômenos originários; tornam-se tais apenas quando, em seu próprio desenvolvimento, um termo mais adequado seria desdobramento, fazem surgir a série das formas históricas concreta das passagens, assim como a folha, ao abrir-se, desvenda toda a riqueza do mundo empírico das plantas.

As séries de formas históricas que se abrem quando do processo de retorno às origens, para Benjamin, associa-se ao processo de articulação histórica dos fatos passados, algo que será trabalhado por ele na retomada da alegoria do anjo da história. Nos apontamentos feitos por Benjamin quando da elaboração das teses sobre a história, em seus arquivos datiloscritos, há uma anotação interessante, que não entrou na redação do texto que fora publicado como a versão que conhecemos das teses. Lembramos, aqui, uma anotação sobre a ideia de "conhecimento do passado": "Na medida em que o passado se concentra no instante - na imagem dialética - ele entra na memória involuntária da humanidade" (Benjamin 2018: 179. Manuscrito 491). A memória involuntária, trabalhada por Benjamin em A modernidade e os modernos, é definida por ele como aquela que corresponde "ao repertório íntimo da pessoa" (Benjamin 1975: 40).

Desse modo, tanto o escavador manoelino quanto o arqueólogo banjaminiano podem ser tomados como sintoma de uma consciência poética que, desde a modernidade, sabe que está mais pobre (Benjamin 2012: 128). Isso significar dizer, também, que, como um poeta romântico-moderno, Barros tem consciência de que sempre habitamos tempos de sofrimento, de violência e de morte, dissimulados pela validade hipertrófica das interpretações abalizadas especialmente pelo iluminismo e seus sucessores. Barros 
é capaz de tecer, por meio de suas alegorias, o rompimento com uma tradição que erige o passado como um lugar quase divinal/edênico, apresentando-nos o sofrimento, a dor, o tédio, o lixo e a morte como ingredientes do humano, do mesmo modo que Benjamin nos alerta da acumulação de ruínas sobre ruínas no passado.

\begin{abstract}
Agora a nossa realidade se desmorona. Despencam-se deuses, valores, paredes... Estamos entre ruínas. A nós, poetas destes tempos, cabe falar dos morcegos que voam por dentro dessas ruínas. Dos restos humanos fazendo discursos sozinhos nas ruas. A nós cabe falar do lixo sobrado e dos rios podres que correm por dentro de nós e das casas. Aos poetas do futuro caberá a reconstrução - se houver reconstrução. Porém a nós, a nós, sem dúvida - resta falar dos fragmentos, do homem fragmentado que, perdendo suas crenças, perdeu sua unidade interior. É dever dos poetas de hoje falar de tudo que sobrou das ruínas - e está cego. Cego e torto e nutrido de cinzas. (Barros 1990: 308-309)
\end{abstract}

Aos poetas resta falar: o verbo falar descende do latim fabulāre, que significa contar, narrar. Na língua portuguesa, reconhece a proferição por meio da oralidade. $\mathrm{O}$ eu lírico manoelino, apesar de se manifestar por escrito, escreve de modo reiterativo sobre a necessidade de que o poeta fale.

Para o eu lírico manoelino, passou o tempo das realidades eternas e dos passados grandiosos, cabendo ao poeta falar sobre as ruínas, os (ex)combros. ${ }^{5} \mathrm{O}$ eu lírico escreve no presente, com compostura e dignidade, sobre a necessidade presente e futura do poeta falar, de modo desnudo, dos fragmentos/feridas e da podridão. Em meio à necessidade de falar, há uma referência duvidosa sobre a possibilidade da reconstrução: "Aos poetas do futuro caberá a reconstrução - se houver reconstrução". A nosso ver, a reconstrução, mesmo que possível, é desnecessária, uma vez que, segundo Gagnebin (2013: 43),

A verdade da interpretação alegórica consiste neste movimento de fragmentação e de desestruturação da enganosa totalidade histórica; [...] Se a interpretação alegórica é uma forma privilegiada de saber humano, é porque ela expõe à luz do dia esta ligação entre significação e historicidade, temporalidade e morte, uma ligação que, somente ela, fundamenta o único saber verdadeiramente positivo do homem [...]

A interpretação alegórica à qual se refere Gagnebin foi desenvolvida pelo próprio Benjamin como exercício analítico quando elaborou a tese IX "Sobre o conceito de história”, tendo como imagem o Angelus Novus, de Paul Klee. Sobre as teses, Michel Löwy (2005: 37), em suas pesquisas sobre o legado benjaminiano, escreve:

Um documento, ainda inédito, que pude consultar no Arquivo Scholem na biblioteca da Universidade Hebraica de Jerusalém, mostra, sem sombra de dúvida, que o próprio título das 
teses foi inspirado em um manuscrito inédito de Scholem, de que certamente Benjamin tinha conhecimento, intitulado Thesen über den Begriff der Gerechtigkeit [Teses sobre o conceito de justiça], datado de '1919 a 1925'. Ao ler esse texto, nos damos conta de que Benjamin não se inspirou apenas no título, mas também no conteúdo do manuscrito.

É importante notarmos que Benjamin não faz, tanto nas teses quanto em seus outros escritos, um exercício interpretativo solitário e abstrato. Mais adiante, Löwy (idem: 38) declara: "Os conceitos de Benjamin não são abstrações metafísicas, mas relacionam a experiências históricas concretas”. O que o pensador alemão solicita de nós, seus leitores de todos os tempos, é que façamos, também, interpretações alegóricas como as demonstradas por ele. Trata-se, pois, de questionar o limite de nossa possibilidade/capacidade de abordar, destroçar e analisar detalhadamente um objeto ao qual nós mesmos estamos presos, como que em estado de atordoamento pela rapidez das coisas. Acompanhemos a lição de Benjamin na tese IX.

'Minhas asas estão prontas para o vôo (sic),

Se pudesse, eu retrocederia

Pois eu seria menos feliz

Se permanecesse imerso no tempo vivo.'

Gerhard Scholem, Saudação do anjo

Há um quadro de Klee que se chama Angelus Novus. Representa um anjo que parece querer afastar-se de algo que ele encara fixamente. Seus olhos estão escancarados, sua boca dilatada, suas asas abertas. $O$ anjo da história deve ter esse aspecto. Seu rosto está dirigido para o passado. Onde nós vemos uma cadeia de acontecimentos, ele vê uma catástrofe única, que acumula incansavelmente ruína sobre ruína e as dispersa a nossos pés. ${ }^{6}$ Ele gostaria de deter-se para acordar os mortos e juntar os fragmentos. Mas uma tempestade sopra do paraíso e prende-se em suas asas com tanta força que ele não pode mais fechá-las. Essa tempestade o impele irresistivelmente para o futuro, ao qual ele volta as costas, enquanto o amontoado de ruínas diante dele cresce até o céu. Essa tempestade é o que chamamos progresso. (Benjamin 1986: 226)

A primeira notação é a epígrafe de Gerhard Scholem, excerto de um texto intitulado "Saudação do anjo". Trata-se do mesmo Scholem, cujo prenome era Gershom, a que Löwy (2005: 37) se refere quando de suas pesquisas sobre Benjamin na Universidade Hebraica de Jerusalém. Assim, a imagem do anjo como alegoria foi sugerida pela leitura do texto de Scholem, acoplada à imagem pictórica sugerida pelo desenho de Paul Klee, o Angelus Novus.

É conveniente observar que Benjamin, envolvido com o marxismo, opõe-se à ideia de progresso, lendo no texto de Scholem e interpretando na tese IX a imagem do anjo 
como o sujeito que atravessa os tempos, sentindo-se inadequado em todos eles, o que nos leva a concordar com Löwy quando ele escreve: "[...] o ataque à ideologia do progresso não é feito em nome do conservadorismo passadista, mas da revolução" (idem: 20). Löwy observa que esse tom subversivo já está posto desde 1915, por ocasião de uma conferência intitulada "A vida dos estudantes":

Há uma concepção de história que, confiando na infinitude do tempo, distingue apenas o ritmo dos homens e das épocas que rápida ou lentamente avançam pela via do progresso. A isso corresponde a ausência de nexo, a falta de imprecisão e de rigor na exigência que ela faz do presente. (Benjamin apud idem: 20)

Aqui lemos o ataque a uma noção continuísta da história como se ela fosse uma sucessão/um amontoado do que quer que seja, defendendo que se escute a exigência que ela própria faz do presente e que se leiam com precisão e rigor os elementos que ela própria oferece a seus interpretadores. Mesmo a ideia de revolução como geradora de cegueira deve ser ressignificada naquilo que vulgarmente a trata como invasão violenta e ameaçadora da liberdade humana.

Assim, seguindo a orientação de Löwy (2005), desde o início de sua experiência como pensador, a tensão se instala como leitmotiv das ideias de Benjamin, o que não lhe permite se ater a qualquer conceito sem problematizá-lo. A ameaça da dissolução e da mediocridade, encarnada no discurso benjaminiano como sintoma do progresso, pode ser ultrapassada se o leitor apreender o anúncio do anjo de Klee, que não é o anúncio de uma boa nova, mas a advertência para que nos defendamos da tempestade, opondo-nos a ela de modo crítico e criativo. Para que tenhamos essa postura diante da tempestade do progresso, é preciso que passemos, também, pela tese IX de Benjamin, pois, como nos alerta Löwy (2005: 87),

\footnotetext{
A tese [9] se apresenta como o comentário de um quadro de Paul Klee, que Benjamin adquirira quando jovem. Na realidade, o que ele descreve tem pouca relação com o quadro: trata-se fundamentalmente da projeção de seus próprios sentimentos e idéias (sic) sobre a imagem sutil e despojada do artista alemão.
}

Vejamos então o Angelus Novus, de Paul Klee. 


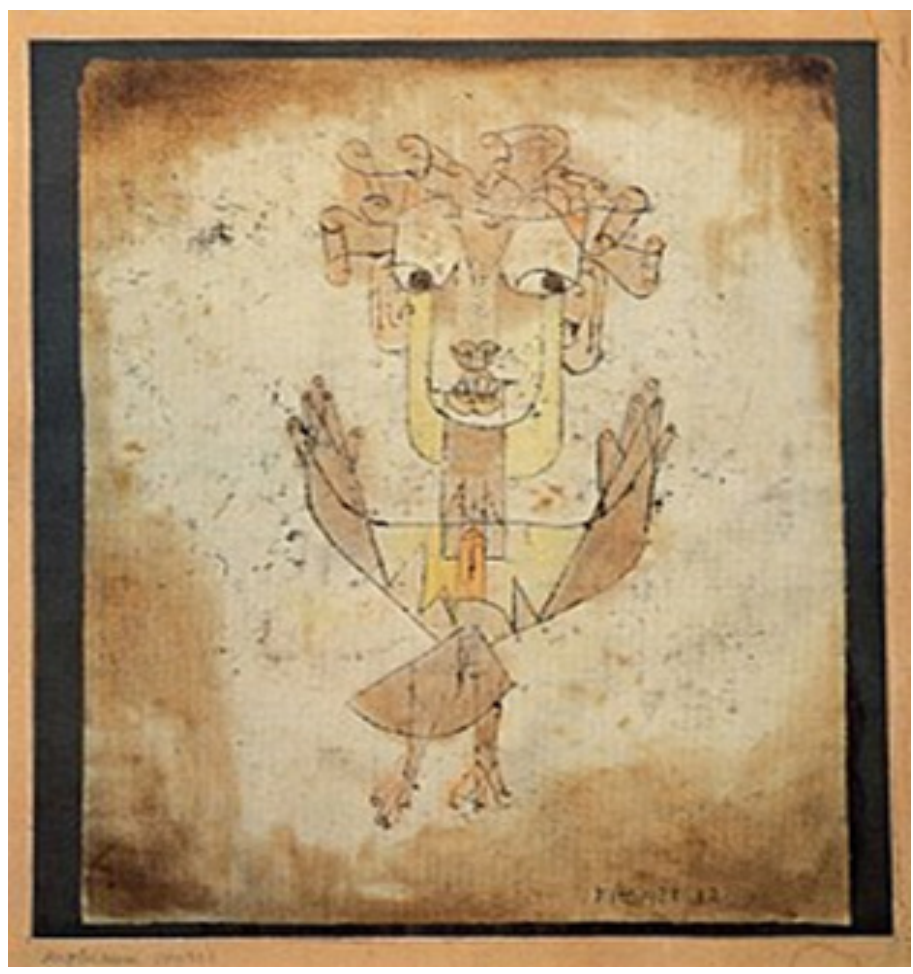

(Klee, 1920. Angelus Novus. Disponível em: https://www.imj.org.il/en/collections/199799.

Acesso em: 25 mar. 2020)

Se a interpretação alegórica de Benjamin sobre o quadro de Klee tem ascendência barroca, Michel Foucault (2016), em Isto não é um cachimbo, tratando da obra de Magritte, Klee e Kandinsky, aponta para uma virada no processo de representação da arte, promovida, sobretudo, por esses três artistas. Segundo Foucault, do século XV ao $X X$, dois princípios reinavam na pintura ocidental: o primeiro afirmava a separação entre a representação plástica e a referência linguística, baseada na ideia de subordinação, ou seja, "[...] ou o texto é regrado pela imagem ou a imagem é regrada pelo texto" (Foucault 2016: 39), de modo que o princípio geral era o estabelecimento de uma hierarquia entre as duas formas de representação, ora pesando a visualidade, ora a textualidade. 0 segundo princípio era o da semelhança entre a coisa e a afirmação visual sobre a coisa. Em outras palavras, bastava que uma imagem se assemelhasse com uma coisa para que se instaurasse no jogo da pintura um enunciado e uma relação evidentes (Foucault 2016). A imagem ficava, assim, submetida a um discurso de verdade que aprisionava as relações de sentido. O fato de Foucault mencionar Klee, Kandinsky e Magritte se dá porque foram artistas que romperam com os dois princípios supramencionados. Para o espaço deste ensaio, interessa-nos como Foucault vislumbra a postura de Paul Klee. Ele é toma- 
do como aquele que aboliu o princípio da soberania nas artes, ao colocar em destaque, segundo Foucault (idem: 41),

[...] num espaço incerto, reversível e flutuante (ao mesmo tempo tela e folha, toalha e volume, quadriculado do caderno e cadastro da terra, história e mapa) a justaposição das figuras e a sintaxe dos signos.

Considerando o Angelus Novus, em uma leitura baseada em Foucault, podemos tomá-la como uma obra em que a superposição dos traços embaralham-se com a imagem que se cria. O que importa não é mais a subordinação dos princípios, ao contrário, o que prevalece é a noção de que a representação criada na tela não se dá de/em uma só vez. O que salta aos olhos no Angelus Novus é a sensação de superposição de formas e de tons que tornam visíveis os limites entre si, porém sem ter o aspecto de espaço/tempo interrompido. Por outro lado, não há um aspecto de continuidade. O que ocorre então na gravura de Klee?

A leitura proposta por Löwy (2005: 89) para a tese IX de Benjamin explica que

A estrutura significativa da alegoria é baseada em uma correspondência - no sentido baudelairiano - entre o sagrado e o profano, a teologia e a política, que atravessa cada uma das imagens. Para uma das figuras da alegoria, os dois sentidos nos são dados pelo próprio texto: o correspondente profano da tempestade que sopra do Paraíso é o Progresso, responsável por uma "catástrofe sem trégua" e por um 'amontoado de escombros que cresce até o céu.

Na esteira da leitura de Löwy, o progresso é herdeiro dos princípios iluministas que desembocaram na modernidade. O progresso também pode ser tomado como um sintoma da modernidade, não sendo, porém, reconhecido como tal pela sociedade. Qual seria o papel do anjo da história?

O Anjo da História gostaria de parar, de cuidar das feridas das vítimas esmagadas sob os escombros amontoados, mas a tempestade o leva inexoravelmente à repetição do passado: novas catástrofes, novas hecatombes, cada vez mais amplas e destruidoras. (idem: 90)

Para interpretar alegoricamente não somente o Angelus Novus, mas também a tese IX, como o fez Löwy, a literatura está disponível para articular a tarefa de compreender as imagens e também de concebê-las de modo a engendrar uma atitude crítica diante delas. Porém, não qualquer literatura. A literatura dos (ex)combros é capaz dessa tarefa, com o apego/apelo ao fragmento.

O que jaz em ruínas, o fragmento significativo, o estilhaço: essa é a matéria mais nobre da criação barroca. Pois é comum a todas as obras literárias desse período acumular incessan- 
temente fragmentos, sem objetivo rigoroso, confundindo estereótipos com enriquecimento artístico, na incansável expectativa de um milagre. (Benjamin 1984: 200)

O ponto de convergência entre a tese IX, a poesia de Manoel de Barros e a gravura de Klee é o fragmento/a ferida. É no fragmento/na ferida que enxergamos o pormenor, aquilo que em geral não tem importância. Segundo Benjamin (idem: 196-198), é no mundo profano que o pormenor não tem relevância e na alegoria o mundo profano é, a um só tempo, exaltação e desvalorização. O anjo, conforme lido por Benjamin, aponta para o signo da catástrofe, com um olhar ambíguo que fita, ao mesmo tempo, o passado esfacelado e indiciado por suas ruínas e o futuro sugerido como incerto e sob ameaça. 0 anjo benjaminiano ressurge nos poemas de Barros como que para afirmar, pela sua própria presença estranha e desconfortável, a relação, sempre tensa, que a poesia e o pensamento poético mantêm com o tempo presente. Podemos estender o que assinalou Gagnebin (1997: 123) sobre a figura do anjo de Benjamin para os poemas de Barros: neles reside a subversão da "[...] idéia mesma de uma posição estável, de uma pátria definitivamente conquistada, de um enraizamento substancial, seja ele de ordem teórica ou existencial".

No caso da poesia de Manoel de Barros, a imagem do pormenor dá o tom de sua dicção poética. Lembremos, por exemplo, o poema "O cisco", de Tratado Geral das Grandezas do Ínfimo, obra com projeções monumentais, como o próprio título aponta: há nele o cruzamento vertical das grandezas com o pormenor, o ínfimo. A tensão disposta entre os eixos da grandiloquência retórica de um tratado escalado para projetar o olhar poético no pormenor, nesse caso o "cisco", é um recurso poético de Barros capaz de captar o encontro de uma percepção sensível com um momento de reflexão filosófica.

\footnotetext{
[...] O cisco há de ser sempre aglomerado que se iguala a restos.

Que se iguala a restos para obter a contemplação dos poetas.

Aliás, Lacan entregava aos poetas a tarefa de contemplação dos restos.

E Barthes completava: Contemplar os restos é narcisismo.

Ai de nós!

Porque Narciso é a pátria dos poetas.

Um dia pode ser que o lírio nascido nos monturos empreste qualidade de beleza ao cisco.

Tudo pode ser.

Até sei de pessoas que propendem a cisco mais do que a seres humanos.

(Barros 2010: 400)
}

Como uma lupa, o esforço de captação da imagem busca o ínfimo. O instante captado marca o ponto de encontro do olhar sensível do poeta, capacitado para perceber o 
cisco, ou mesmo o nascimento do lírio, e o ponto de inflexão crítica do pensamento, ao expandir o pormenor para uma questão filosófica. As referências a Lacan, Barthes e a Narciso garantem o aprofundamento questionador do poema no momento mesmo em que a imagem do cisco serve de alegoria ao próprio fazer poético. É como se a poesia fosse o próprio pormenor.

Em outra obra, Gramática Expositiva do Chão, lemos o poema "A máquina de chilrear e seu uso doméstico”, em um diálogo com a obra de Paul Klee.

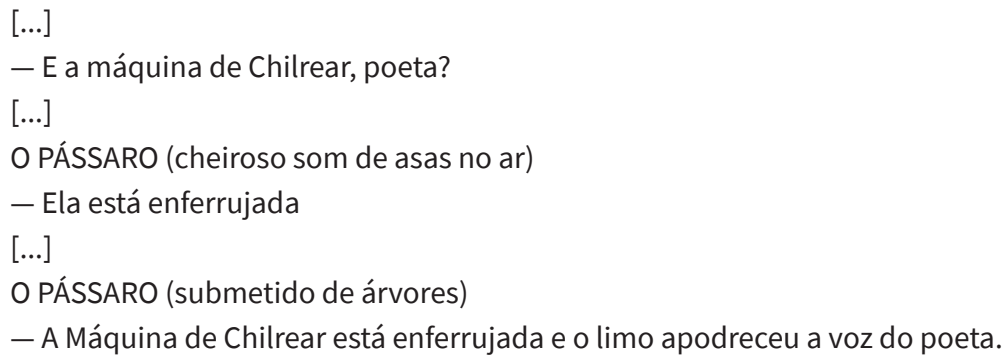

(Barros 1990: 170-171)

As marcas das ferrugens na máquina apontam para a marca do tempo, isto é, da passagem do tempo. A imagem da máquina vê-se submetida ao escrutínio da morte ao se notar os índices que vão maculando sua índole: a ferrugem, o limo, o apodrecimento da voz do poeta, em contraste com a voz do pássaro. Ao final do poema é possível observar o resto do poeta (da voz que representa o poeta): "Os indícios de pessoas encontrados nos homens eram apenas uma tristeza nos olhos que empedravam" (idem: 172). A ferida aberta na voz do poeta aponta para os indícios do que não se vê, não se ouve, mas deixa sua marca no tempo.

Ainda na Gramática Expositiva do Chão, outro poema cujo tema da máquina ocupa lugar central é "A máquina: a Máquina segundo H.V., o jornalista”, que denota os rastros de um passado erigido em ruínas. O título, enigmático em si, apresenta as siglas "H.V." como abreviações de um nome que não pode ser revelado, tendo como único qualificativo "o jornalista”, de modo bastante genérico. Há, aí, uma tensão importante, pois a singularidade da máquina segundo H.V. que não se esclarece contra o efeito genérico do qualificativo que escamoteia um fato passado. Os versos do poema não esclarecem muita coisa tampouco:

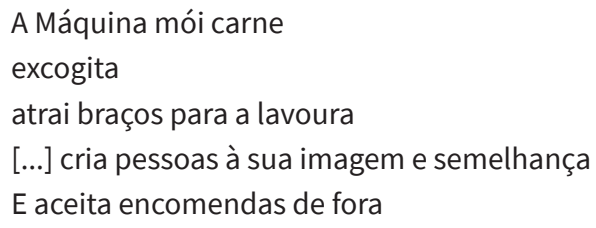


ponto é reconhecível o tópico da figura do homem miserável, esse que tem o "direito inalienável ao sofrimento", diante da máquina do mundo (imago mundi). É legível no poema de Barros o processo de escavação de uma memória que nos apresenta o tema da recusa da máquina do mundo. Nesse ponto, vale mencionar, em menção comparativa, a argumentação de José Miguel Wisnik (2018: 226) ao ler a máquina do mundo drummondiana:

[...] a tônica da recusa, nessa interpretação, não estaria na não aceitação do encantamento pré-moderno implicado nas antigas cosmogonias, mas na recusa do desencantamento tecno-ciêntífico atrelado, conforme Adorno e Horkheimer, ao poder regressivo e remitizante oculto na técnica e no esclarecimento modernos, que acabariam por oferecer-se, também a estes, como uma 'explicação cabal do universo' e uma enganosa e 'total explicação da vida'.

Nesse ponto, há a convergência de pensamento entre Barros, Benjamin e Klee, que não aceitam ser engolidos pela máquina do mundo. Diante da figura enigmática do anjo de olhos e de asas abertas, petrificado pelo horror que se passa diante da visão, a escrita desses homens sugere que o passado apagado pelo tempo contínuo do progresso, ao ser escavado pela (re)elaboração da linguagem poética, desvela uma escrita fantasmagórica que se dá por imagens.

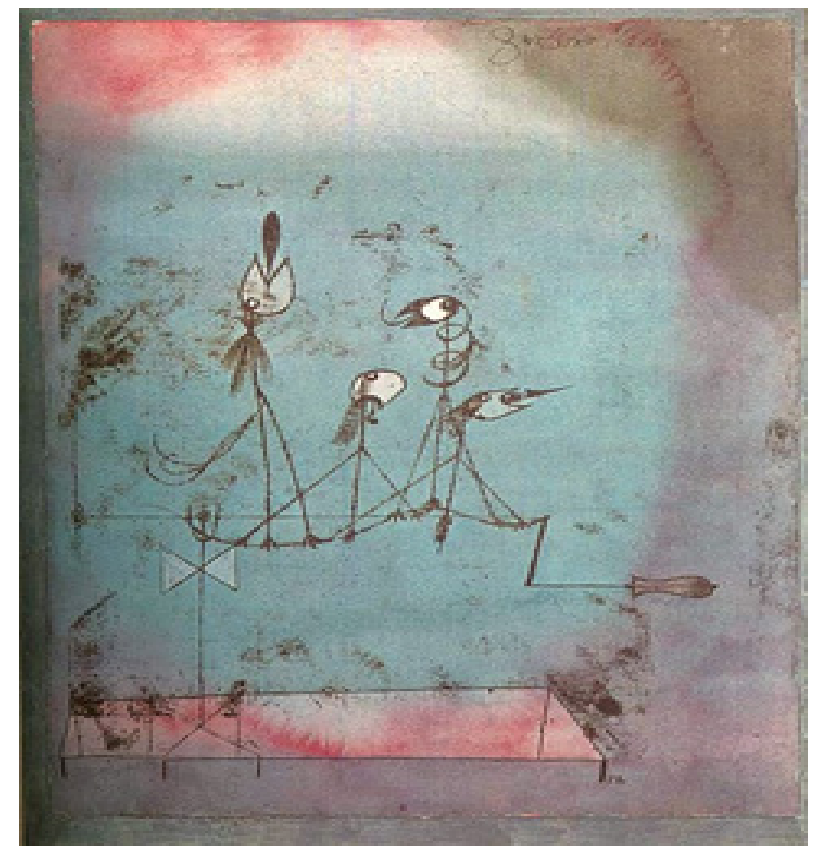

(Klee, 1922. A máquina de chilrear. Disponível em: https://br.pinterest.com/ pin/737605245190196340/\#. Acesso em: 25 mar. 2020) 
No quadro de Klee, uma pintura feita de aquarela, tinta e guache em papel, reconhecemos traços semelhantes aos do Angelus Novus, desta feita, com a sobreposição de imagens de pássaros e a máquina, representada por sua manivela. Embaixo da manivela, parece haver uma estrutura semelhante a um esquife, uma imagem de morte. Pensamos aqui na aparência de um esquife em conexão com uma consideração de Georges Didi-Hubermann (2017), retirada do livro Cascas, fruto singular de sua visita ao Museu de Auschwitz-Birkenau. Em tempo: ele também é um, assim como Gagnebin e Löwy, dos grandes leitores de Benjamin na contemporaneidade.

Podemos pensar que a superfície é o que cai das coisas: que advém diretamente delas, o que se separa delas, delas procedendo, portanto. E que delas se separa para vir rastejando até nós, até a nossa vista, como retalhos de uma casca de árvore. Por menos que aceitemos nos abaixar para recolher alguns pedaços. (Didi-Hubermann 2017: 70. Itálico do autor)

A casca também faz parte do tronco. O problema é que ela é o pormenor, é o que fica no chão depois como resto. Por outro lado, ela é a casca da ferida que machucou/ machuca e está disposta/disponível para que fabulemos as mais várias narrativas sobre a grandiosidade ou não da árvore.

\section{NOTAS}

* Paulo Eduardo Benites de Moraes (Universidade Federal de Rondônia - UNIR) Docente do Departamento de Línguas Estrangeiras (DLE) e do Mestrado Acadêmico em Estudos Literários (MEL) da UNIR. Doutor em Estudos Literários pela UFMS. Estágio pós-doutoral pela Universidade Católica Dom Bosco (UCDB). Líder do Grupo de Pesquisa em Poéticas Moderna e Contemporânea (CNPq/UNIR).

** Rosana Cristina Zanelatto Santos (Universidade Federal de Mato Grosso do Sul - UFMS) Docente da UFMS. Doutora em Letras pela USP. Estágio pós-doutoral pela UnB. PQ-CNPq. 
${ }^{1}$ Utilizamos as expressões "fragmento" e "ferida" de modo equivalente, pois queremos trazer ao leitor a lem-

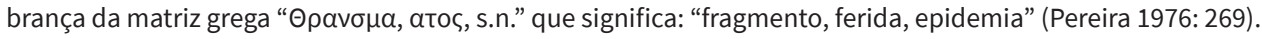
${ }^{2}$ Entrevista publicada em 2006 na Revista Caros Amigos por ocasião dos 90 anos do poeta.

${ }^{3}$ Sobre o assunto, sugerimos a leitura de Revolta e melancolia: o romantismo na contracorrente da modernidade, de Michel Löwy e Robert Sayre (São Paulo: Boitempo, 2015).

${ }^{4}$ Como um trabalho já consolidado e aprofundado sobre a obra Ensaios Fotográficos, de Manoel de Barros, cita-se, o estudo: Grácia-Rodrigues, Kelcilene. De corixos e de veredas: a alegada similitude entre as poéticas de Manoel de Barros e de Guimarães Rosa. Araraquara, 2006. 318 f. Tese de Doutorado. Tese (Doutorado, Estudos Literários) - Faculdade de Ciências e Letras, UNESP. Disponível em: http://wwws.fclar.unesp.br/agenda-pos/ estudos_literarios/785.pdf.

${ }^{5}$ A expressão combro é dicionarizada. No Grande dicionário da língua portuguesa (2010), ao procurarmos "combro", somos remetidos à expressão cômoro, que significa: "1 pequena elevação isolada de terreno; montículo; 2 [regionalismo] parede de suporte de terreno em socalco; 3 canteiro; alegrete. Do latim cumŭlu-, 'montão'” (2010: 390).

${ }^{6}$ Neste ponto da tradução de Sergio Paulo Rouanet, ficamos intrigados se a dispersão das ruínas se faria "a nossos pés" e aos pés do anjo. Recorremos então ao texto em alemão, onde se lê: "Wo eine Kette von Begebenheiten vor uns erscheint, da sieht er eine einzige Katastrophe, die unablässig Trümmer auf Trümmer häuft und sie ihm vor die Füße schleudert" (Benjamin, Walter. Disponível em: https://www.uni-erfurt.de/fileadmin/ public-docs/Literaturwissenschaft/avl/Scans_Seminare_Menke_WiSe12_13/Krise_rebellion_Aufstand/Benjamin_UEber_den_Begriff_der_Geschichte.pdf. Acesso em: 25 mar. 2020). Entendemos que o período "[...] und sie ihm vor die Füße schleudert” refere-se às ruínas (sie) que a catástrofe arremessa (schleudert) aos pés do anjo (ihm), ele próprio uma alegoria do ser humano. No entanto, para os objetivos deste texto, continuaremos nos fiando na tradução de Rouanet.

${ }^{7} \mathrm{Na}$ obra de Manoel de Barros há outros momentos nos quais os indicativos históricos são simbolizados. A obra Face Imóvel é um bom exemplo desse traço na poética do autor, acentuadamente vinculada à lírica de guerra. Sobre esse tema ver o artigo: "A lírica de guerra na poética de Manoel de Barros", de Paulo Eduardo Benites de Moraes e Josemar de Campos Maciel, publicado em: Literatura: teoría, historia, crítica 22-1 (2020), pp. 179-194. Disponível em: http://www.scielo.org.co/scielo.php?script=sci_arttext\&pid=S0123$-59312020000100179 \&$ lang=pt 


\section{BIBLIOGRAFIA}

Arendt, Hannah (1987), “Walter Benjamin 1892-1940”, in Homens em tempos sombrios. Tradução Denise Bottmann, São Paulo, Companhia das Letras: 133-176.

Barros, Manoel de (2006), "Entrevista: Três momentos de um gênio", Revista Caros Amigos, n 117 , ano X, São Paulo: 29-33.

-- (1990), “Conversas por escrito", in Gramática expositiva do chão: poesia quase toda, Rio de Janeiro, Civilização Brasileira: 305-343.

-- (2010), Poesia completa, São Paulo, Leya.

-- (2008), Memórias inventadas: as infâncias de Manoel de Barros, São Paulo, Planeta do Brasil.

-- (1997), Livro Sobre Nada, Rio de Janeiro, Record.

-- (2003), Ensaios Fotográficos, Rio de Janeiro, Record.

Benjamin, Walter (1984), Origem do drama barroco alemão, trad. Sergio Paulo Rouanet, São Paulo, Brasiliense.

-- (1986), "Sobre o conceito de história”, in Magia e técnica, arte e política. Ensaios sobre

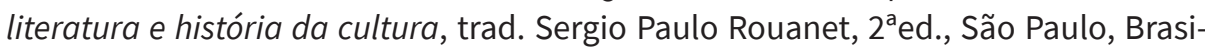
liense: 221-232.

-- (1975), A modernidade e os modernos, trad. Heindrun Krieger Mendes da Silva e Tania Jatobá, Rio de Janeiro, Tempo Brasileiro.

-- (2018), O anjo da história, trad. João Barrento, Belo Horizonte, Autêntica Editora.

-- (2006), Passagens, trad. Irene Aron e Cleonice Paes Barreto Mourão, Belo Horizonte, Editora UFMG.

Bornheim, Gerd (1992), A invenção do novo, in Novaes, Adauto (org.), Tempo e História, São Paulo, Companhia das Letras.

Didi-Hubermann, Georges (2017), Cascas, tradução André Telles, São Paulo, Editora 34. Foucault, Michel (2016), Isto não é um cachimbo, trad. Jorge Coli, São Paulo, Paz \& Terra. Gagnebin, Jeanne Marie (2013), “Alegoria, Morte, Modernidade”, in História e narração em Walter Benjamin, São Paulo, Perspectiva: 31-53.

-- (1997), "O hino, a brisa e a tempestade: dos anjos em Walter Benjamin”, in Sete aulas sobre linguagem, história e memória, Rio de Janeiro, Imago: 123-138.

Löwy, Michael (2005), Walter Benjamin: aviso de incêndio: uma leitura das teses "Sobre o conceito de história", trad. Wanda Nogueir Caldeira Brant, Jeanne Marie Gagnebin, Marcos Lutz Müller, São Paulo, Boitempo.

Nunes, Benedito (2013), O tempo na narrativa, São Paulo, Loyola.

Paz, Octavio (2012), O arco e a lira, trad. Ari Roitman e Paulina Wacht, São Paulo, Cosac Naify.

Pereira S.J., Isidro (1976), Dicionário grego-português e português-grego, 5. a ed., Porto, Livraria Apostolado da Imprensa.

Ribeiro, Helano Jader (2020), “A memória des-figurada de Walter Benjamin”, Revista Sig- 
nótica UFG, Goiânia, v. 32, n. 1: 1-16.

Santo Agostinho (1980), Confissões, trad. J. Oliveiras dos Santos e A. Ambrósio de Pina,São Paulo, abril cultural (Os Pensadores).

Wisnik, José Miguel (2018), Maquinação do mundo. Drummond e a mineração, São Paulo, Companhia das Letras. 